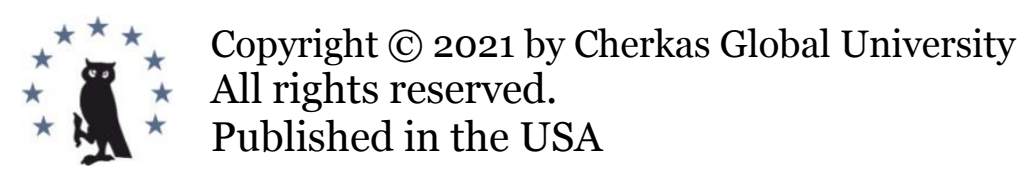

European Journal of Contemporary Education

E-ISSN 2305-6746

2021. 10(4): 924-942

DOI: 10.13187/ejced.2021.4.924

https://ejce.cherkasgu.press

IMPORTANT NOTICE! Any copying, reproduction, distribution, republication (in whole or in part), or otherwise commercial use of this work in violation of the author(s) rights will be prosecuted in accordance with international law. The use of hyperlinks to the work will not be considered copyright infringement.

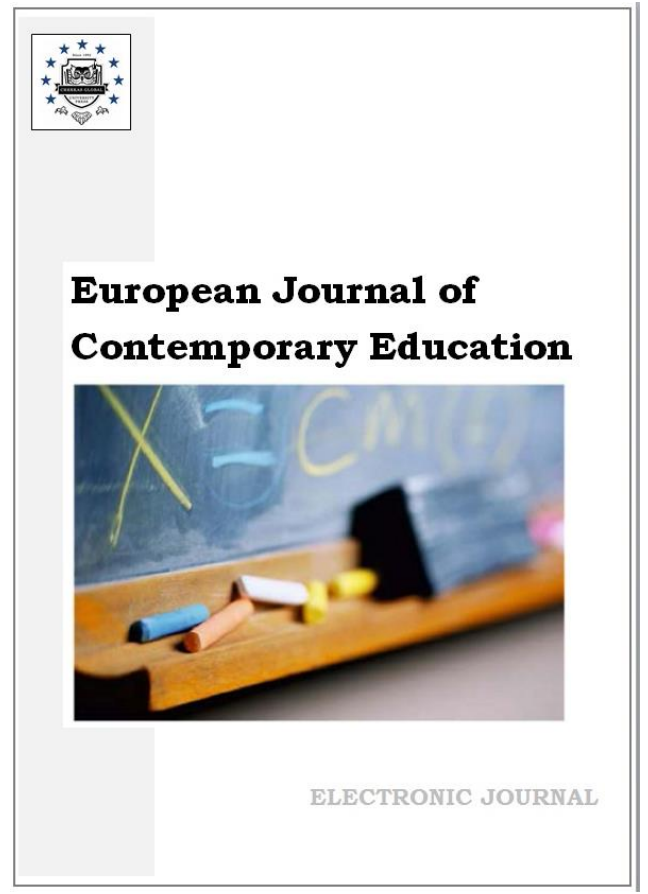

\title{
Creation of Effective Cooperation between Russia Youth and Foreign Higher Institutions in Research and Development Sphere
}

\author{
Yuliya M. Gruzina a, Marina A. Ponomareva a , *, Liliya V. Prikhodko a, Khvicha P. Kharchilava a \\ a Financial University under the Government of the Russian Federation, Moscow, \\ Russian Federation
}

\begin{abstract}
Currently, one of the most important factors of functioning and development of world society at the present stage is youth, which makes up about a fifth of the population of Russia and $18 \%$ of the world's population. Youth plays an important role as a factor of social change, renewal, initiative, energy in the implementation of reforms and changes.

Self-realization and self-organization of youth is possible on the basis of youth enterprises that contribute to the formation of their mentality, increase the level of their culture, the implementation of conceived projects and ideas, as well as aspirations.

One of the priority directions of the development of universities is international activity, which must be an obligatory part of the education of specialists in various professional fields, who can know their way around foreign and domestic technologies freely and are competitive on the labour market.

Russian universities are cooperating with international universities increasingly, what was caused by transitioning to the Bologna education process, Russia's entry into the WTO, the expansion of international cooperation.

The article considers the directions of development of research cooperation of Russian and foreign youth enterprises; presents the best practices of cross-border interaction of youth enterprises; reviews the ways of development of research cooperation of Russian and foreign youth enterprises; analyses the system of criteria and algorithm of effective cooperation in the development of Russian and foreign youth research enterprises; suggests methodological recommendations for the competitive selection of Russian satellite universities as basis for research with the participation of youth.

\footnotetext{
* Corresponding author

E-mail addresses: MAPonomareva@fa.ru (M.A. Ponomareva), ymgruzina@fa.ru (Yu.M. Gruzina)
} 
Keywords: education system, Moscow education, education strategy.

\section{Introduction}

International cooperation has always been a necessary component of the development of university science, however, only relatively recently it has become an important part of the mission and an obligatory part of the development strategy of educational organizations. Research activities can be developed in strictly closed systems in rare cases. Research and innovation become always integrative and open. Especially important in this regard is the formation of an effective system to support the research youth cooperation with foreign universities and researchers.

One of the fundamental criteria for creating an effective system of engagement of young people in research activities and motivating them to further development of a research career is the presence of an organizational and research partnership in the management of the organization and in the activities of universities, where enterprises actively cooperate with universities and universities with international colleagues. The implementation of this activity is carried out in several directions, among which it is possible to distinguish the next below:

- firstly, educational activities that allow students to get education at partner institutes and universities from foreign countries,

- secondly, scientific activities, which ensure the active participation of students in international student events, such as scientific student conferences, forums, symposiums, seminars.

Youth organizations, movements, socio-political associations have a huge impact on youth politics, allow them to build a creative atmosphere and to develop the competences and skills of young people. Today youth enterprises affect all areas of development and functioning of modern international relations. Moreover, there is a tendency to universalize the nature of modern youth enterprises, which are becoming more and more universalized, and participate in world politics very actively (Vovenda, 2013).

International youth movements and organizations make it possible to unite young people from different countries and have a significant impact on international youth politics.

International youth organizations are increasingly going beyond the usual traditional forms of activity (informal education, youth exchanges, volunteering, youth movements, camps, joint social projects, etc.) and are implementing international student cooperation in various areas of cooperation with various structures and enterprises.

Youth movements and organizations have a huge impact on the formation of the system of international relations. For modern society at every stage, the attitude towards youth organizations is very relevant in their various directions. Youth organizations play a very important role in the internationalization of youth relations, and also, act as a major factor in the development of interaction between different countries, universities, enterprises. Globalization and the desire for new forms of associations, the strengthening of the role of international activities increases the importance of youth international organizations.

The largest and most significant international organizations include:

- The International Union of Students (Prague, Czech Republic) is an international nongovernmental organization founded in 1946, uniting national student organizations of different countries.

- JCI (Junior Chamber International, International Youth Chamber) (USA, Chesterfield) is a non-commercial organization that unites over two hundred thousand young leaders and entrepreneurs aged 18 to 40 years in more than hundred countries around the world (Junior Chamber International, 2021).

- The World Festival of Youth and Students (WFMS) (Moscow, Russia) is an irregular festival of left-wing youth organizations, held since 1947. The program of the festivals includes sports competitions in various sports, political seminars and discussions, concerts, mass celebrations, as well as the obligatory colourful procession of delegations (WFMS, 2021).

- AIESEC (Canada, Montreal) is an international independent non-commercial non-political organization, fully managed by young people aged 18 to 29 years. The aim of AIESEC is to maintain peace and realize human potential through the development of leadership skills in young people. The main activity of AIESEC is the organization of international exchanges and internships; AIESEC also organizes forums and other social important projects (AIESEC, 2021). 
- The World Economic Forum (Switzerland, Geneva) became the organizer of the Global Shapers Community in 2011. It represents urban sites that are located all over the world created and managed by extraordinary young people of 20-30 years (shapers) who have achieved exceptional success in various fields of their activities and, most importantly, who want to contribute to the development of the whole society. Members of this Community can put forward ideas and entrepreneurial innovations to solve world problems in various directions. In Russia, such communities operate in various cities including Moscow, St. Petersburg, Kaliningrad, Kazan and others.

- The International Union of Young Socialists (International Union of Socialist Youth, IUSY) (Vienna, Austria) founded in 1907 unites organizations from around the world, including countries of Africa, America, Asia, Europe. The Russian organization Russian Social Democratic Youth Union (RSDSM) is also a member of it.

- WYSE (World Youth Service Enterprise) (World Organization for Youth, London) is a worldwide educational charity enterprise specializing in the education and development of new leaders, nurturing skills such as servant and visionary leadership in new emerging leaders.

While analysing youth enterprises, we can identify features and criteria, which generalize them (Table 1).

Mobility becomes the key to the success of young people in the context of social and society's changes. It is this group of the population that is most open to solve the problems of stereotypical views, which does not allow society to make the most effective decisions in its most different areas. As a result, it is young people who determine the uniqueness and success of many youth projects in the international sphere, including the development of cross-border cooperation.

Young people are the link of society who is able to use the contact function of the border in the process of interaction with representatives of various cultural and political camps more effectively. Due to the features described, this socio-age group plays a determining role in the execution of projects of cross-border interaction and cooperation.

It is young people who should develop internal motivation and personal engagement in solving state tasks by increasing the level of involvement in the processes of cross-border interaction. In this case, not only individual socio-age groups, but also the society, in general, will be able to reach a qualitatively new level of interaction, due to which the goals and objectives associated with improving the quality of population life and strengthening relations between countries will be executed (Sapryka i dr., 2016).

Table 1. Features and Criteria of Youth Enterprises

\begin{tabular}{|c|c|c|}
\hline $\begin{array}{l}\text { Features of Youth } \\
\text { Enterprises }\end{array}$ & Criteria Description & Examples \\
\hline Purpose availability & $\begin{array}{l}\text { A value idea that mobilizes } \\
\text { forces for joint activities of } \\
\text { young people }\end{array}$ & $\begin{array}{l}\text { Maintaining a distinctive culture } \\
\text { (bruderboard); assistance in the } \\
\text { education and development of youth; } \\
\text { religious goals. }\end{array}$ \\
\hline $\begin{array}{l}\text { Availability of } \\
\text { enterprise members }\end{array}$ & $\begin{array}{l}\text { Voluntary entry into } \\
\text { enterprise, free exit from } \\
\text { them / fixed membership }\end{array}$ & $\begin{array}{l}\text { The number of personnel of the } \\
\text { "Panchasila Youth" is } 3 \text { million people. } \\
\text { Membership is free and voluntary. }\end{array}$ \\
\hline $\begin{array}{l}\text { Independence } \\
\text { management }\end{array}$ & $\begin{array}{l}\text { Self-government and joint } \\
\text { social creativity }\end{array}$ & $\begin{array}{l}\text { Organization of festivals and } \\
\text { conferences (Festival of Youth and } \\
\text { Students), participation in meetings, } \\
\text { demonstrations }\end{array}$ \\
\hline $\begin{array}{l}\text { Pronounced } \\
\text { orgstructure }\end{array}$ & $\begin{array}{l}\text { Securing a certain position } \\
\text { for each member of the } \\
\text { organization }\end{array}$ & $\begin{array}{l}\text { Presence of Presidents and Chairmen } \\
\text { of organizations; instructors and } \\
\text { cadets (National Cadet Corps) }\end{array}$ \\
\hline
\end{tabular}




\begin{tabular}{|l|l|l|}
\hline $\begin{array}{l}\text { Availability of rules and } \\
\text { code of conduct }\end{array}$ & $\begin{array}{l}\text { The establishment of } \\
\text { behavior patterns, as well as } \\
\text { the guarantee of the right of } \\
\text { joint activity with an } \\
\text { independent choice of its } \\
\text { types and forms }\end{array}$ & $\begin{array}{l}\text { Similar rules may be a ban on the use } \\
\text { of force in the framework of activities, } \\
\text { organizations }\end{array}$ \\
\hline $\begin{array}{l}\text { Predominance of young } \\
\text { people in the structure } \\
\text { of association }\end{array}$ & $\begin{array}{l}\text { An additional criterion. The } \\
\text { organization's activities can } \\
\text { be aimed at working with } \\
\text { young people, and its } \\
\text { members can be people of } \\
\text { different ages }\end{array}$ & $\begin{array}{l}\text { The presence of students, young } \\
\text { scientists and activists among the staff } \\
\text { of the association (Australian Union) }\end{array}$ \\
\hline $\begin{array}{l}\text { Availability of the } \\
\text { charter or program }\end{array}$ & $\begin{array}{l}\text { Following a certain order in } \\
\text { the implementation of the } \\
\text { association of its activities }\end{array}$ & $\begin{array}{l}\text { The activities of the Congress and the } \\
\text { Board are regulated on the basis of the } \\
\text { Charter (Youth Association of Finno- } \\
\text { Ugric Folk) }\end{array}$ \\
\hline
\end{tabular}

\section{Materials and methods}

Effective cooperation of research activities and organizational policy in organizations gives the young generation more confidence in achieving success in the development of their research potential and encourages them to choose a research career for their future. It is important to understand that often research structures and structures making management decisions and determining the development policy of an organization can prioritize research activities in different manner, therefore it is very important that they interact with each other as strategic partners. The Georgalakis and Rose model demonstrates how different types of research results are integrated into one system that meets the needs of all organizational subsystems (Figure 1).

The Georgalakis and Rose model takes into account four types of cooperation in research and organizational policy, but particular emphasis should be put on the segment associated with the construction and strengthening of professional networks (Georgalakis, Rose, 2019). It is the creation of professional research networks, international relations, contacts that contributes to the sustainable and effective development of research activities and forms a stable foundation for young professionals and for the development of their research activity.

The building of a "horizontal" research cooperation of Russian young scientists with foreign universities, along with many positive phenomena for domestic science, such as the expansion of the young scientists' horizon, acquisition of new knowledge and skills by them, primarily poses the problem of brain drain to Russian higher education and science.

It is known from historical practice the solution to prohibit and to build barriers will give a backlash, what means, that young scientists will form a strong desire to realize their talent abroad. In this regard, a more pragmatic approach to solve this problem will be the creation of a system for social support and encouragement of youth development in the research sphere, including a "live" acquaintance with the system of scientific research in foreign institutions.

The practical experience of leading foreign educational organizations with research orientation was summarized, within the framework of this study to substantiate the criteria and algorithm of the process of forming an effective "horizontal" research cooperation of Russian youth with foreign universities and organizations.

Within the framework of this research a sociological survey of 200 Russian and foreign students at the Financial University was conducted. The survey was aimed to determine the effectiveness of different methods for development of research cooperation to form the algorithm for building this type of cooperation subsequently. 


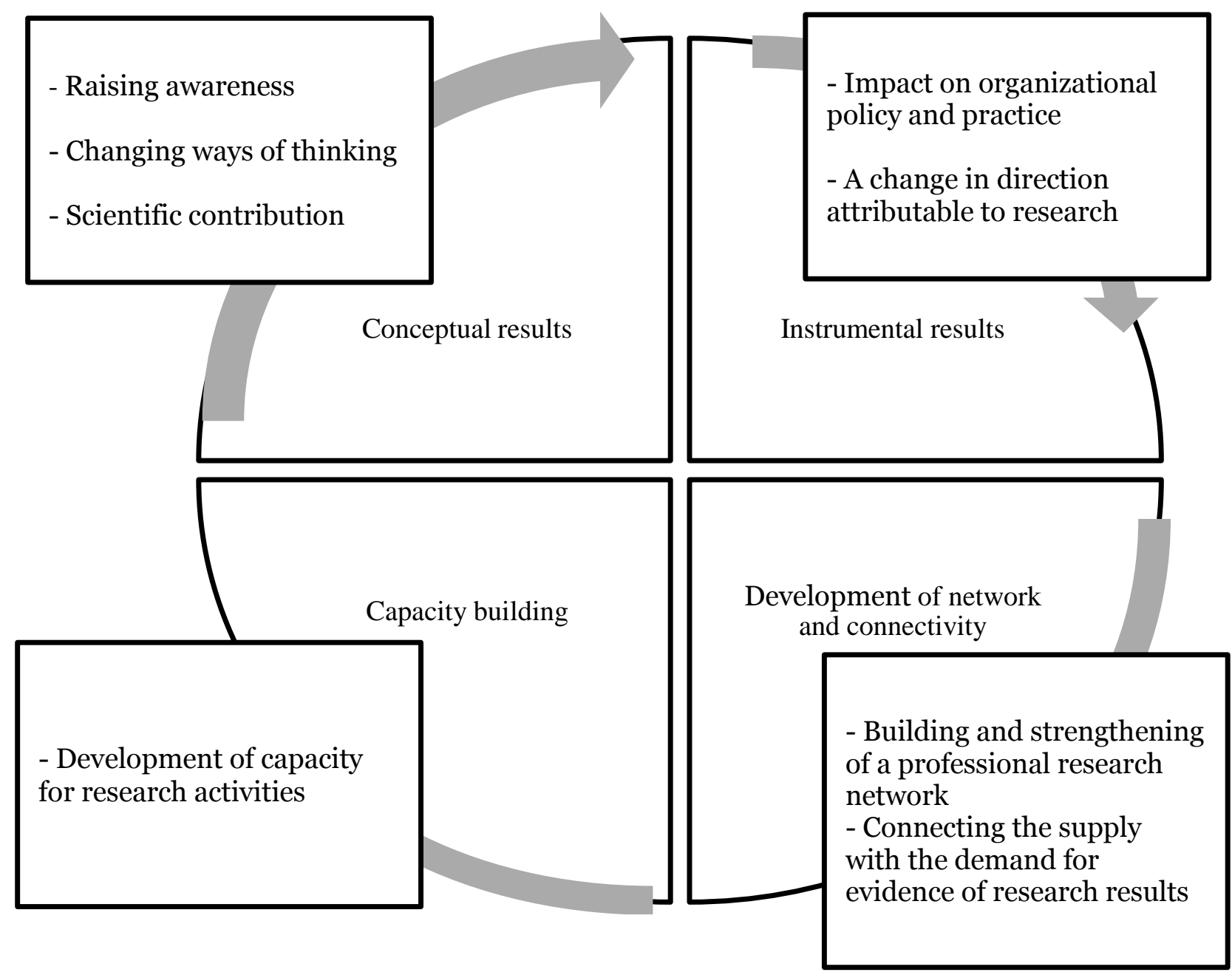

Fig. 1. Integration of research results (Georgalakis, Rose, 2019)

The obtained data are presented both in the form of a traditional one-dimensional allocation of answers to questions, and in the form of simple rated indexes (i). The relationships between the studied criteria of international research cooperation were summarized while correlation analysis.

The system of criteria for effective "horizontal" cooperation of Russian youth with foreign universities defines criteria which ensure effective international research cooperation of young people.

According to the results of the survey conducted, the average rate demonstrating the importance of research activities for students equaled 6.56 scores out of 10 possible. More than half of the respondents ( $64 \%$ ) take part in research activities.

Students' interest in research activities is primarily determined by opportunities for professional growth. Thus, according to the respondents' opinion, the most effective types of motivation to be involved in research activities are good prospects for employment $(i=0.80)$, opportunities to master professional competencies and to develop necessary personalities $(i=0.76)$, as well as opportunities to implement their own scientific ideas $(i=0.76)$ and expand their social capital $(i=0.76)$ (Figure 2$)$.

Monetary compensation is not highly rated motivation for students $(i=0.72)$. The opportunity to work in modern laboratories motivates the students to research activities the least motivating for students in the least degree $(i=0.69)$.

Preparation and publication of articles in scientific journals (43.3\%) and participation in student conferences of the Financial University (42.3\%) are the most popular forms of scientific activity what students are engaged in (Figure 3). 
Employment prospects

Development of professional and personal competencies

The opportunity to implement your own scientific ideas

Live communication with foreign colleagues

Monetary compensation

Opportunity to be published in the journals highly rated

Access to new science information

Opportunity to work in modern laboratories

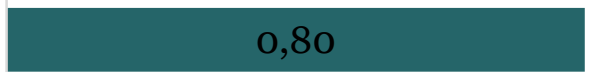

\section{0,76}

\section{0,76}

\section{0,76}

\section{0,72}

\section{0,71}

\section{0,71}

0,69

Fig. 2. Evaluation of motivation forms for performing research activities, indexes range from o to 1 Source: compiled by the authors

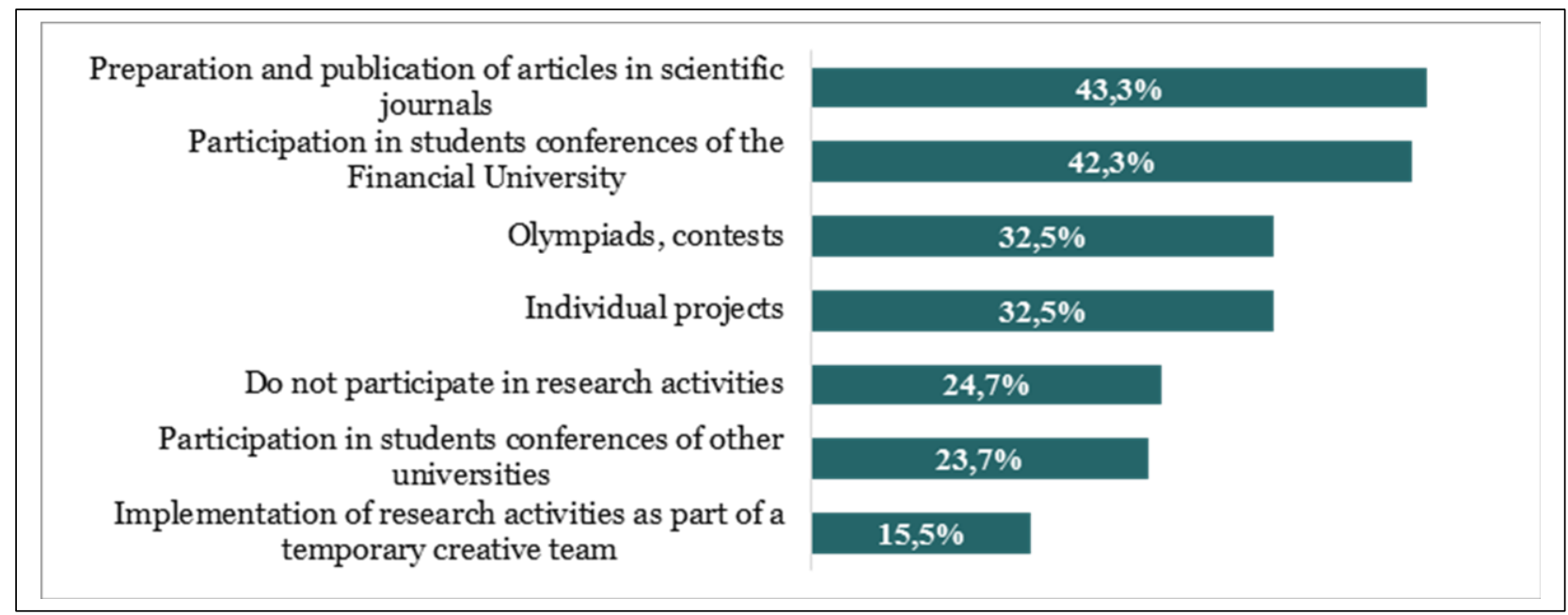

Fig. 3. Forms of scientific activities performed by students of the Financial University Source: compiled by the authors.

Every third respondent indicated that he takes part in olympiads and competitions, as well as is engaged in individual projects. The respondents attend less external student conferences $(23.7 \%)$ and participate in the research projects as part of temporary creative teams $(15.5 \%)$.

When analyzing the dependence of the forms of scientific activities, performed by students, on the quantity of study years in the higher education system (from 1 to 4 courses for bachelor's degree programs), the Pearson criterion $\chi^{2}$ was calculated (Table 1). The value of $\chi^{2}=52.964$ with a significance of 0.001 . The significance of the test is less than 0.05, so the hypothesis that there is a connection between the course in which students learn and the choice of the form of scientific activity is refuted. 
Table 1. Forms of scientific activities performed by students of the Financial University according to study courses

\begin{tabular}{|l|c|c|c|c|}
\hline Forms of scientific activities & $\begin{array}{c}\text { 1st } \\
\text { course }\end{array}$ & $\begin{array}{c}\text { 2nd } \\
\text { course }\end{array}$ & $\begin{array}{c}\text { 3rd } \\
\text { course }\end{array}$ & $\begin{array}{c}\text { 4th } \\
\text { course }\end{array}$ \\
\hline $\begin{array}{l}\text { Participation in student conferences of the } \\
\text { Financial University }\end{array}$ & $51,2 \%$ & $24,4 \%$ & $17,1 \%$ & $7,3 \%$ \\
\hline $\begin{array}{l}\text { Participation in student conferences of } \\
\text { other universities }\end{array}$ & $45,7 \%$ & $19,6 \%$ & $28,3 \%$ & $6,5 \%$ \\
\hline $\begin{array}{l}\text { Preparation and publication of articles in } \\
\text { scientific journals }\end{array}$ & $46,4 \%$ & $25,0 \%$ & $21,4 \%$ & $7,1 \%$ \\
\hline Non-participation in scientific activity & $66,7 \%$ & $14,6 \%$ & $12,5 \%$ & $6,3 \%$ \\
\hline $\begin{array}{l}\text { Implementation of research activities as } \\
\text { part of temporary creative teams }\end{array}$ & $43,3 \%$ & $26,7 \%$ & $26,7 \%$ & $3,3 \%$ \\
\hline Individual projects & $55,6 \%$ & $19,0 \%$ & $17,5 \%$ & $7,9 \%$ \\
\hline Olympiads, contests & $50,8 \%$ & $27,0 \%$ & $14,3 \%$ & $7,9 \%$ \\
\hline
\end{tabular}

Source: compiled by the authors

Mostly, students are ready to participate in research cooperation as part of any team (53\%), however, $9.1 \%$ of respondents would prefer to conduct research only as part of an international team, $8.1 \%$ of respondents are ready to join their Russian colleagues for scientific research (Figure 4). It should be noted that $14.7 \%$ of respondents prefer to conduct research on their own.

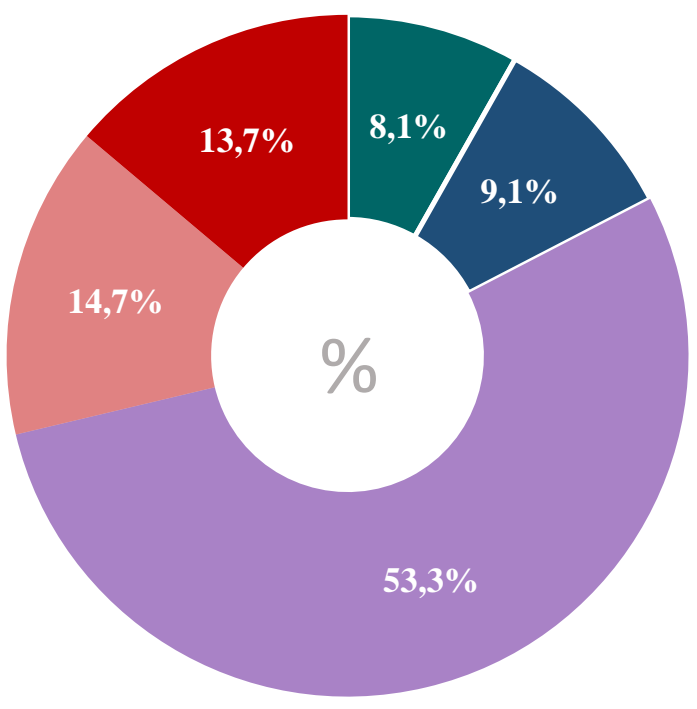

- YES, but only in Russia researchers' team

- YES, but only in international researchers' team

YES, in any team

NO, prefer to conduct research activities individually

- NO, not interesting for me

Fig. 4. Availability of students' desire to join a research cooperation Source: compiled by the authors

When analyzing the motivation of students to start research cooperation, taking into the quantity of study years in the higher education system (from 1 to 4 courses for bachelor's degree programs), the criterion $\chi^{2}=17.439$ with a significance of 0.293 . The significance of the test is greater than 0.1, what shows a statistical relationship between the course which students attend and their motivation to start research cooperation (Table 2). 
Table 2. Readiness of students of the Financial University to begin scientific research cooperation according to study course

\begin{tabular}{|l|r|r|r|r|}
\hline \multicolumn{1}{|c|}{$\begin{array}{c}\text { Readiness to begin scientific } \\
\text { research cooperation }\end{array}$} & 1st course & \multicolumn{1}{c|}{$\begin{array}{c}\text { 2nd } \\
\text { course }\end{array}$} & $\begin{array}{c}\text { 3rd } \\
\text { course }\end{array}$ & \multicolumn{1}{c|}{ 4th course } \\
\hline $\begin{array}{l}\text { YES, but only in Russia researchers' } \\
\text { team }\end{array}$ & $8,30 \%$ & $12,80 \%$ & $0,00 \%$ & $8,30 \%$ \\
\hline $\begin{array}{l}\text { YES, but only in international } \\
\text { researchers' team }\end{array}$ & $7,50 \%$ & $2,60 \%$ & $15,40 \%$ & $33,30 \%$ \\
\hline YES, in any team & $53,30 \%$ & $59,00 \%$ & $53,80 \%$ & $33,30 \%$ \\
\hline $\begin{array}{l}\text { NO, prefer to conduct research } \\
\text { activities individually }\end{array}$ & $15,00 \%$ & $15,40 \%$ & $15,40 \%$ & $8,30 \%$ \\
\hline NO, not interesting for me & $14,20 \%$ & $10,30 \%$ & $15,40 \%$ & $16,70 \%$ \\
\hline
\end{tabular}

The analysis of the best practices, strategies and tactics of supporting talented youth in leading foreign universities, as well as the data of the conducted sociological research allowed the authors to form an updated list of conditions, which are criteria for the development of effective "horizontal" cooperation of Russian youth with foreign universities.

\section{Results}

\section{Expanding access to necessary resources}

The need for an interdisciplinary approach in research aimed at the mutual exchange of ideas and methodologies is often highlighted as an important priority in modern science. Although many motives of research cooperation are equally relevant for both domestic and international cooperation, in order to achieve this goal in an international context, additional aspects should be taken into account. Many research communities are divided along national borders, if not formally, then often in practice, which is dictated by the strategic goals of the main national agencies. Therefore, international research cooperation can offer access to new points of view, ideas, experience and skills. Different national research priorities in specific countries can also determine priorities in the allocation of resources or equipment, therefore, it is international scientific cooperation what allows expanding access to necessary resources limited at the local, regional or national level significantly (Adams, 2012). The forms of this cooperation can be different, for example:

- An information resource is necessary for the formation of young scientists, at least for two next reasons. Firstly, the possibility of working on the problem already solved in a known way is excluded while free access to information about the latest achievements in the field of their scientific interest. Secondly, the publication of their scientific achievements in open sources allows you to declare your idea and, possibly, in controversial situations about author's right.

- Assistance and comprehensive support of students. The culture of assistance to students and talented youth means not just a list of measures, but also constant interaction aimed at developing their personal and professional characteristics, what excludes a priori doing instead of them. Almost all modern universities have a certain structure responsible for promoting young talents. It performs more often an information-accumulating and resource-distributing function since it has certain powers and contacts with external structures interested in cooperation in the research field and ready to provide research financially (grant support system).

- Mentoring as a resource. Participation of students in scientific associations, laboratories, etc., as a rule, is the initial stage of inclusion in scientific life. And the future of young people as researchers depends on what kind of experience they will get at this stage. A big role at this stage is assigned to the academic advisor of the research team: what he represents not only as a scientist, but also as a person; the breadth of his scientific perspectives and general range of interests. The academic advisor, who takes an active position as a scientist, has many connections in the scientific and academic world, what makes it possible to form interdisciplinary research teams, including international ones.

- International grants for research activities. The "horizontal" cooperation of Russian students with foreign colleagues to conduct scientific research in a united team gives more chances 
to win a grant for the implementation of their ideas. As a rule, the competition commissions are more favorable to international creative teams under other equal conditions.

Availability of technical means and other material conditions for conducting research, including the ability to maintain large amounts of data. The greater is the representation of different countries in the youth scientific project the more technical opportunities are for the implementation of the boldest ideas, as representatives of the academic community state, the technical equipment of universities by definition cannot keep up with technology development, primarily information systems. Therefore, while the "horizontal" cooperation for the implementation of research in the international youth team, there is an opportunity to use not only the technical resources of their universities, but also the technical equipment of their partners from the industrial and business sphere. An example of this could be the ability to process large amounts of data. According to the statement of the Academician B. Chetverushkin, Academic Director of the Keldysh Institute of Applied Mathematics of the Russian Academy of Sciences, currently Japan, the USA and China have the most powerful computers with capacity of tens of petaflops (1015 operations per second) at least. In Russia Sberbank has the most powerful computing system: its production capacity is 8 petaflops (Pisarenko, 2021).

The initiation of international youth cooperation is significantly facilitated by international academic mobility programs, which are performed in most of the world's leading educational organizations. Student exchange programs, scholarship mobility support programs allow students to carry out part of their studies and/or research abroad, which is an effective tool for establishing international professional relations for further research activities.

In addition to positive effect international academic mobility programs can have negative consequences in the form of "brain drain" of talented youth. In this regard, it is necessary to develop an effective system of material and non-material motivation for young researchers. Studies show that financial incentives are not always primary for young researchers, as stimulating priorities they highlight the possibility of choosing research areas of great interest to them, the availability of prospects for the development of a scientific career (Dolzhenko et al., 2019). The important stimulating factor for young researchers is the high academic rating of scientific schools and representatives in their organizations.

The important factor for effective research cooperation is to reach agreement on the policy of dissemination of research results and copyrights. It is necessary to discuss this issue at the earliest stage of joint research, before disagreements can become an obstacle to successful research cooperation. Depending on the focus of the research and the expected results, it is also necessary to clarify the policy of cooperation in relation to commercialization and intellectual property rights.

The American Psychological Association has established authorship criteria, which are usually followed by many international peer-reviewed journals in various disciplines (American Psychological Association, 2014). The authorship should reflect the contribution to the research, while the author is considered to be any person involved in the planning of the research, data collection and analysis, drafting of the manuscript or final approval. In this regard, an important aspect is the development of transparent and optimal criteria for determining authorship (co-authorship) for all types of activities within the framework of scientific research.

Creating an effective policy of dissemination of research results requires reaching an agreement on who will be authorized to speak on behalf of the research team. The most important aspects in this context are trust and collegiality.

The construction of an algorithm for effective "horizontal" cooperation of Russian youth with foreign universities is based on the analysis of the best practices and data of the sociological research conducted.

According to the survey, more than $75 \%$ of respondents are ready to participate in international research cooperation (Figure 5). 


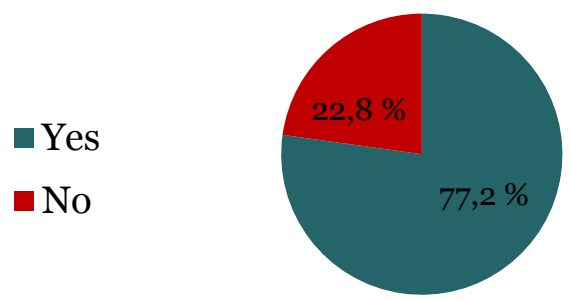

Fig. 5. Readiness to participate in international research cooperation Source: compiled by the authors

According to the participants of the sociological study, the following factors influence the increase of motivation in building effective international research cooperation: live communication with foreign colleagues $(i=0.81)$, the opportunity to become a part of perspective researchers' team $(\mathrm{i}=0.80)$, to be published in highly rated journals $(\mathrm{i}=0.80)$ and to implement author's scientific ideas $(\mathrm{i}=0.80)$ (Figure 6$)$

\begin{abstract}
Live communication with foreign colleagues
To become a part of perspective researchers' team

Opportunity to be published in the journals highly rated
\end{abstract}

The opportunity to implement your own scientific ideas

Access to new science information

Monetary compensation

Opportunity to work in modern laboratories

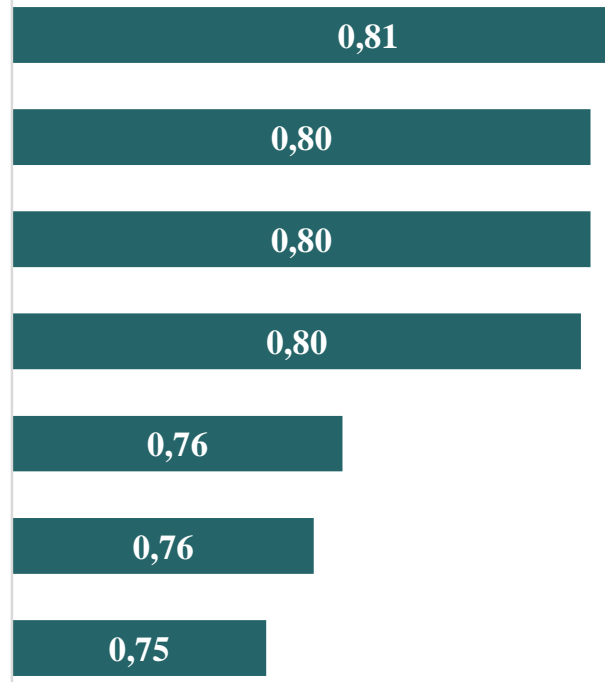

Fig. 6. Assessment of the motivation mechanisms necessary to use for effective research cooperation, indexes range from 0 to 1

Source: compiled by the authors

In addition, students point out the importance of providing access to new scientific information $(\mathrm{i}=0.76)$, fair monetary compensation $(\mathrm{i}=0.76)$ and the opportunity to work in modern laboratories $(\mathrm{i}=0.75)$.

The correlation analysis (the correlation coefficient $(r)$ is an indicator which value varies from -1 to +1 ) made it possible to study the links between various motivation mechanisms for international research cooperation. Thus, it was discovered that the students:

- who highly evaluates the effectiveness of such motivation as the opportunity to implement their own scientific ideas also they highly assess the possibility of access to new scientific information (the r-Spearman coefficient $=0.761$, the correlation is significant at the level of 0.01);

- who highly evaluates the opportunity to work in modern laboratories as an effective motivational factor, they also assess with high score the opportunity to become a part of perspective researchers' team (the $r$-Spearman coefficient $=0.718$, the correlation is significant at the level of 0.01);

- who highly evaluates the effectiveness of such motivation as live communication with foreign colleagues they, also, highly assess the opportunity to become a part of perspective researchers' team (the $\mathrm{r}$-Spearman coefficient $=0.732$, the correlation is significant at the level of 0.01 ). 
The study participants believe that mentoring by more experienced researchers $(\mathrm{i}=0.78)$ and holding face-to-face meetings for scientific disputes and discussions $(i=0.77)$ can significantly contribute to the productive international research cooperation (Figure 7).

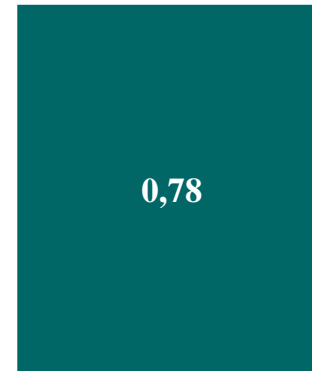

Mentoring by more experienced teachers
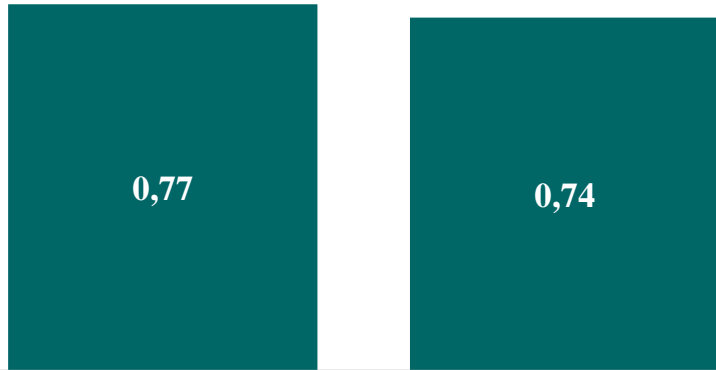

Face-to-face meetings for Workshops, conferences science disputes and discussions

\section{with international} participation

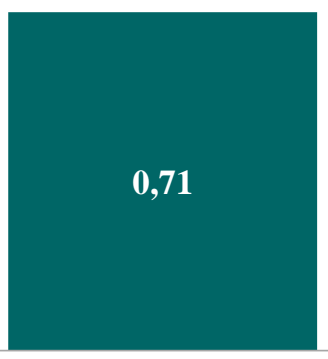

Permanent institutional support

Fig. 7. The importance of aspects ensuring effective international research cooperation, indexes range from 0 to 1

Source: compiled by the authors

Not less important, according to students' opinion, are scientific events with international participation $(i=0.74)$, as well as constant institutional support $(i=0.71)$.

Respondents were offered to consider the University Youth Research Support Center as an institutional support. According to the survey results, almost $70 \%$ would seek for help to the University Youth Research Support Center. About $17 \%$ believe that such a center is absolutely necessary, but they would not turn to it for help. Only less than $5 \%$ of respondents indicate that they do not have a need for a support center for young researchers at the university (Figure 8).

- Yes, I would appeal to such a center for support

Yes, I would not appeal to such a center for support

- There is no such need

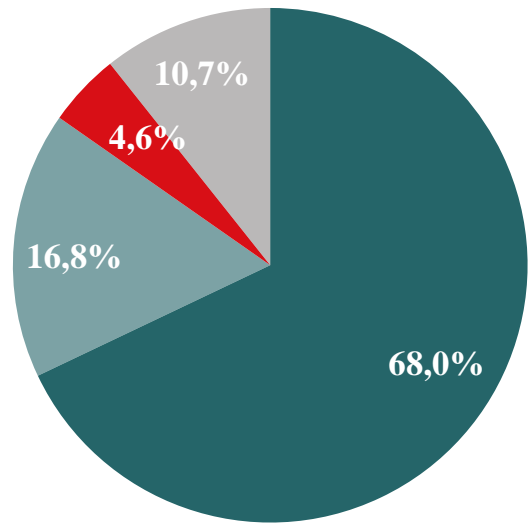

Difficult to answer

Fig. 8. Students' need for a special support center for young researchers at the university Source: compiled by the authors

When analyzing the students' need in a special university support center for young researchers and the quantity of study years in the higher education system (from 1 to 4 courses for bachelor's degree programs), the criterion $\chi^{2}=8,284$ with a significance of 0.506 . The significance of the test is greater than 0.1, therefore, the presence of a statistical relationship between the course and the presence of the need for a special support center for young researchers among students is confirmed, the older the respondent is, the less he needs a special center (Table 3). 
Table 3. Students' need for a special support center for young researchers at the university according to study courses

\begin{tabular}{|l|c|c|c|c|}
\hline $\begin{array}{c}\text { Students' need for a special } \\
\text { support center for young } \\
\text { researchers at the } \\
\text { university }\end{array}$ & $\begin{array}{c}\text { 1st } \\
\text { course }\end{array}$ & $\begin{array}{c}\text { 2nd } \\
\text { course }\end{array}$ & $\begin{array}{c}\text { 3rd } \\
\text { course }\end{array}$ & 4th course \\
\hline $\begin{array}{l}\text { Yes, I would appeal to such a } \\
\text { center for support }\end{array}$ & $70,0 \%$ & $69,2 \%$ & $57,7 \%$ & $66,7 \%$ \\
\hline $\begin{array}{l}\text { Yes, I would not appeal to such } \\
\text { a center for support }\end{array}$ & $14,2 \%$ & $17,9 \%$ & $26,9 \%$ & $16,7 \%$ \\
\hline There is no such need & $4,2 \%$ & $2,6 \%$ & $3,8 \%$ & $16,7 \%$ \\
\hline Difficult to answer & $11,7 \%$ & $10,3 \%$ & $11,5 \%$ & $0,0 \%$ \\
\hline
\end{tabular}

Source: compiled by the authors

The algorithm for effective "horizontal" international cooperation of young researchers has been developed based on the analysis (Figure 9). It should be noted that the developed algorithm, in which an important role is assigned to the University Research Support Center, offers a solution to the most common problems of arranging international cooperation of students at universities, however, is not the only one possible way to organize support for scientific research of young scientists. The organization of research activities is influenced by the individual characteristics of young researchers, or rather, the level of independence of young scientists (youth scientific associations) while conducting scientific research. However, it should be noted that information and institutional support can provide significant assistance even to completely independent teams of researchers in difficult situations.

Based on the survey results, the algorithm for building an effective model of international research cooperation of students should begin with interaction with teachers-mentors who are actively engaged in scientific research. At this stage, the teacher's interest in involving students in the sphere of their scientific interests is important, as well as the willingness to consider a wider range of scientific problems, including topics proposed by students.

This work represents an algorithm for a general situation when a student with the idea of scientific research does not have information about who of teachers at his university is working on a similar topic. In this case, the student/young researcher can be supported by the University Research Support Center (URSC, hereinafter referred to as the Center), whose tasks include several types of support: academic, informational and resource; security; organizational.

Academic support consists in finding a mentor. It is assumed that such a Center will have information about teachers/researchers of the university and the scope of their scientific interests, as well as about foreign scientists from partner universities and organizations and the scope of their scientific activities. A student (a group of researchers) forms a scientific concept and formulates research hypotheses in cooperation with a mentor.

Information and resource support is provided by accumulating and updating the following information:

- scientific directions in which research is conducted in foreign partner universities,

- planned (ongoing) international projects for which partners are being searched,

- authoritative scientific publications and conditions for publishing the results of scientific research,

- research support funds, grants, competitions,

- announcements of upcoming conferences, forums, seminars.

The topic of scientific research may be revised (corrected) at the stage of familiarization with information about research directions and youth scientific associations in foreign partner organizations, about current or planned international projects. Such kind of information will be especially useful when forming an international research team for interdisciplinary research. After considering several options, the most suitable one is selected at that moment. Thus, a request for the creation of an international youth research team is formed. 


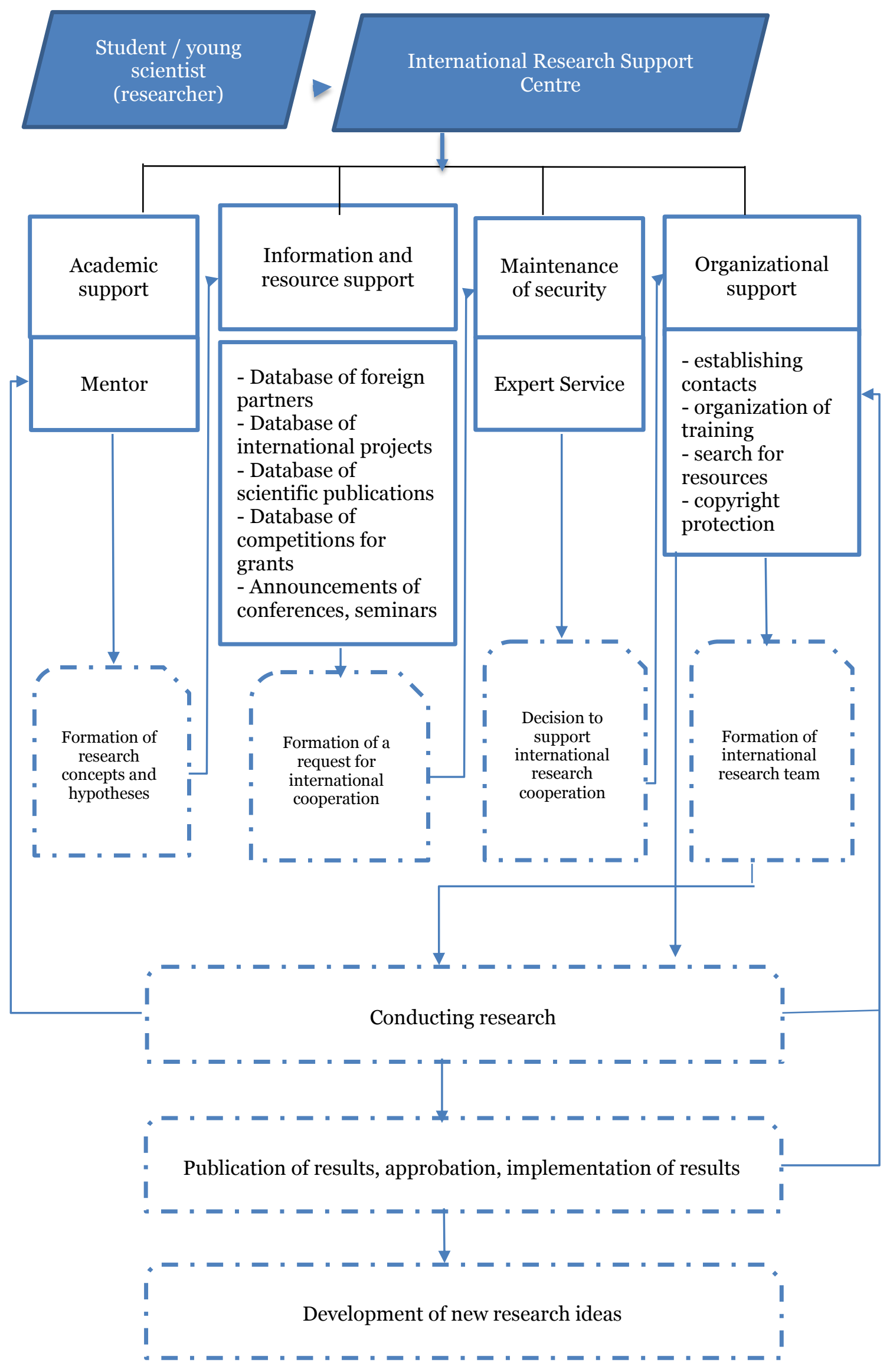

Fig. 9. Algorithm for the formation of international horizontal research cooperation Source: compiled by the authors 
It should be noted that acquaintance and communication at conferences, forums and seminars remains one of the reliable ways to find like-minded people for future research projects. This way allows you to strengthen and develop cooperation if they are organized by partner universities, as well as with a high probability to find new reliable partners for scientific research.

Updated information about competitions for foreign grants makes it possible to provide research with material resources - equipment, materials, etc. Of course, the chances of winning the competition increase if foreign partners with a "good" history of projects performed with the involvement of grants are engaged in the competition.

Maintenance of security means the observance of national security, mainly related to technical and technological areas of research. In each state there is a large list of "closed" topics related to the defense, biological, technical, economic and information security of the country, which cannot be the subject of research by an international scientific team. To avoid possible collisions, the functions of the Center include also addressing materials on planned research to appropriate expertise.

Organizational support consists in helping to establish contacts with potential research partners. Upon reaching an agreement to participate in research, an international youth team is created. At the same time, the team may have several mentors representing all the parties involved. For student/youth research teams, both at the beginning and in the process of research, it will be important to conduct lectures and seminars on topics necessary to replenish knowledge in the subject area, exchange views on ongoing research. The support of the Center will be very important for student groups to arrange such meetings. While scientific research there may be a need for resources for conducting research, participating in conferences, and publishing the results of scientific research. In this case, the databases available at the Center can help. An important aspect of organizational support is the settlement of copyright issues for each of the parties of the study.

Also, a real help to students and young researchers may be the possibility of financing publications in reputable journals through the Center, which will first send the article for content review.

At the end of the research, the question about implementation of the study results appears in case if the research has the applied nature, or new ideas are being developed for further research.

To assess the feasibility of investments into educational infrastructure, including international scientific cooperation of students as the main stakeholders of the higher education system, the authors have developed a model of the profitability of such investments. At the same time, the financing of the education system in this model is considered as a process aimed at fulfillment of potential human capital of the state, i.e. increasing the turnover of human capital.

Human capital is definitely a limited resource that directly impacts the development of the economic system and indirectly generates its own sub-growth, what is the basis for the statement of the thesis about the renewable nature of this resource and its limitations respectively. According to the authors, the limitation of the resource directly depends on its ability to renew. Thus, air, which is an unlimited resource in accordance with the law of energy

In other words, human capital, as the basis of economic growth and development, can be considered unlimited up to the possibility of self-renewal, the condition of which is the object of this article - the education system, which is created and developed through the process of accumulation of human capital and, at the same time, is one of the main actors in the process of its reproduction.

However, the human capital of organizations providing educational services is exclusively an internal resource, and external financing (both public and private) is required for a sufficient level of production of the considered basis of the sapiocentric economic system, what appears a simulacrum of a post-industrial society.

The described process is the basis for the formation of the counter-damping wave structure of the society in sapiocentric systems and, in particular, in its cores, which can be considered as science-intensive spheres of the economy. The counter-damping wave or "trampoline" effect is a controlled process of strengthening economic growth by increasing the amplitude of the net return on investment into human capital, which can be estimated according to the following model: 


$$
\left\{\begin{array}{c}
R O I_{t}=A \cdot e^{\lambda \cdot t} \cdot \cos (\omega \cdot t-\phi) \\
\overline{R O I_{t}}=\sum_{1}^{t} \frac{\Delta G D P_{t}}{U I_{t-1}}=\sum_{1}^{t} \frac{\Delta G D P_{t}}{\delta_{t} \cdot G_{t}}=\sum_{1}^{t} \frac{\Delta G D P_{t}}{\alpha+\beta \cdot U I_{t-1}+\gamma \cdot G D P_{t}}
\end{array}\right.
$$

where $R O I_{t}$ - profitability of investment into education infrastructure within period t, $\overline{R O I_{t}}-$ cumulative profitability over the period 1 to $\mathrm{t}, A$ - constant coefficient reflecting amplitudes of counter-damping oscillations $t$ - observed period, $\lambda$ - inverse coefficient by the effect from investment, $\phi$ - phase of the cycle, $G D P_{t}$ - measure (indicator) of economic development sapiocentric system or, in the particular case, the GDP of the state in period t, $U I_{t}$ - investments into education infrastructure within period $\mathrm{t}, G_{t}-$ consolidated state budget within period $\mathrm{t}, \delta_{t}-$ ratio of consolidated state budget within period $t$, related to education expenditures, $\alpha, \beta, \gamma-$ constant coefficients of formation of investments into education infrastructure.

The generated model can be visualized as reverse damping waves or counter-damping oscillations (Figure 9, right) and as a profitability plane (Figure 9, left).

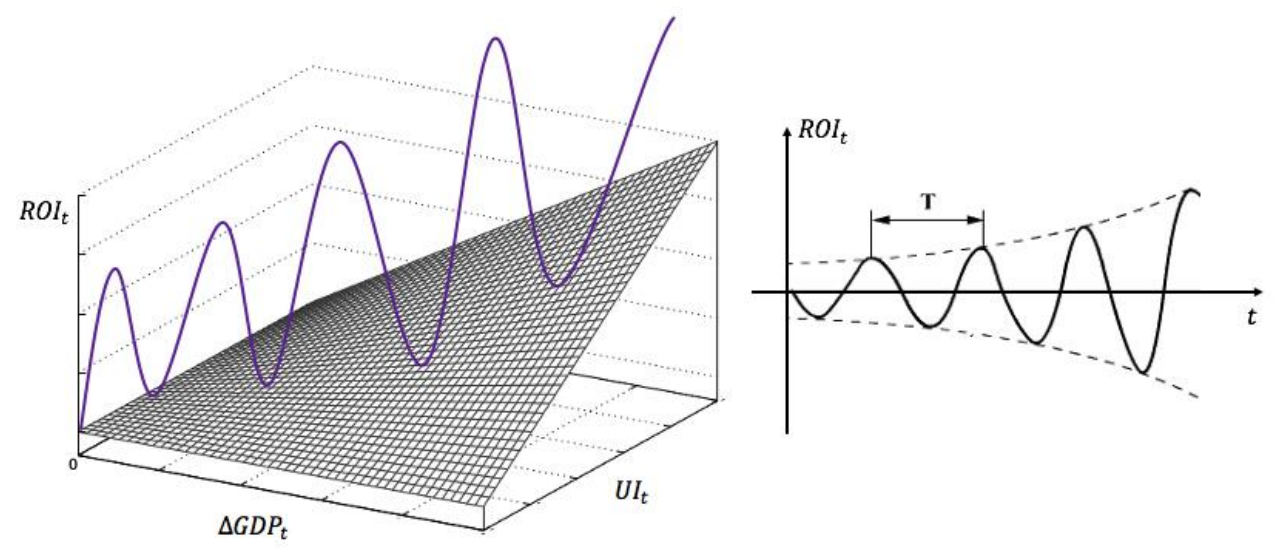

Fig. 9. "Trampoline" effect by investing in educational infrastructure Source: compiled by the authors

It is important to highlight that the final model for evaluating the hypothesis is based on the decomposition of the complex model presented above, which makes it possible to achieve the siplification of the effect of counter-damping oscillations in a sapio-oriented economy of the following type of wave surface (Figure 10):

$$
R O I_{t, l n}=\left(\Delta G D P_{t, l n}-U I_{t, l n}\right)=A_{l n}+\lambda \cdot t+\ln (\cos (\omega \cdot t)) .
$$

The final model is differentiated by the forecast period that is used for its construction. So, in the long-term period (Figure 11a) the surface converts into a linear one, what justifies the strategic importance of the educational sphere for the economic system and for the Russian economy, in particular. In the short-term period (Figure 11b), on the contrary, the surface is distorted increasing the quantity of noise, what is a consequence of monopolistic competition on the market of educational services and high differentiation of quality.

The assessment of the generated model was carried out on the basis of data on expenditures of the consolidated state budget from 2006 to 2020 published by the Ministry of Finance of the Russian Federation and data on GDP at current prices for the same period issued by Rosstat. In absolute values, these indicators have a high degree of correlation (Figure 12), that's why the authors decided to clean the final model from autocorrelation. Moreover, to improve the quality of the model, the source data, as well as the model itself, are logarithmic. 


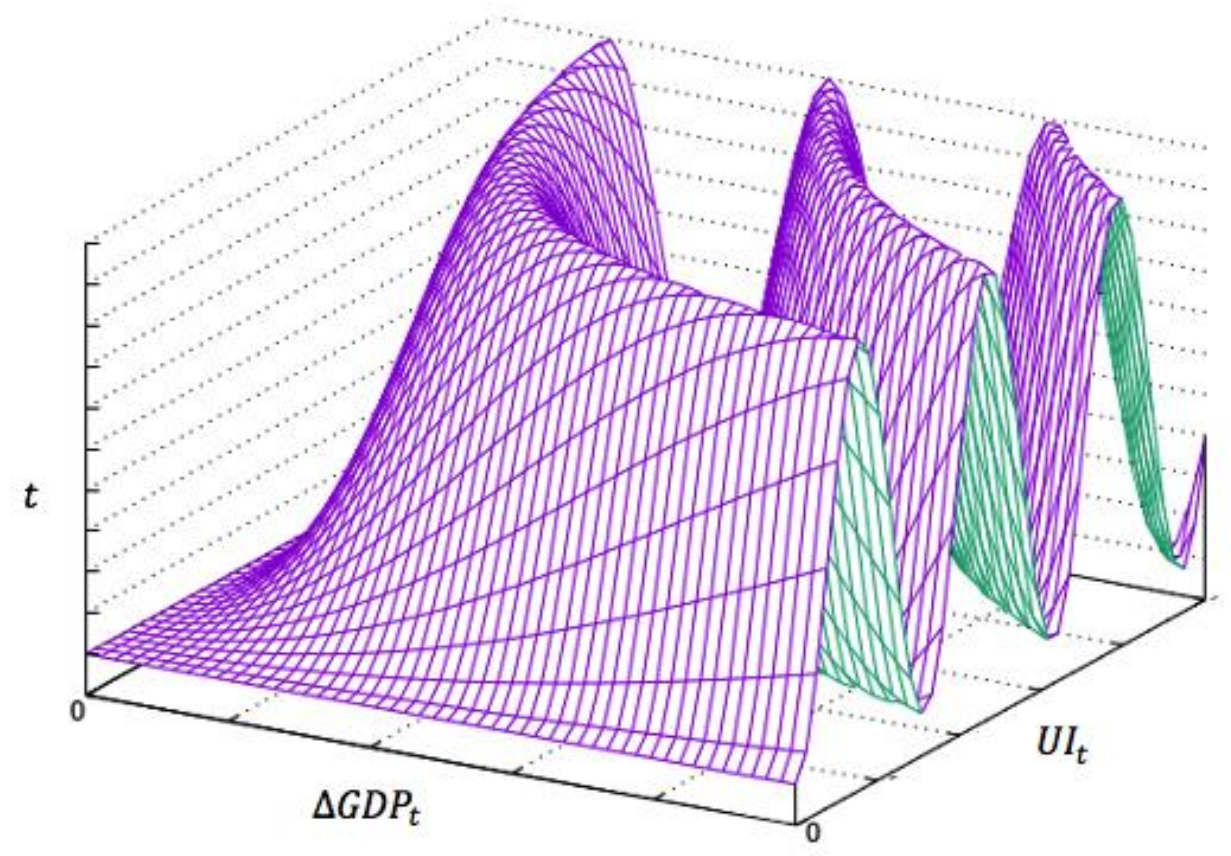

Fig. 10. Visualization of counter-damping oscillations in sapiocentric systems Source: compiled by the authors

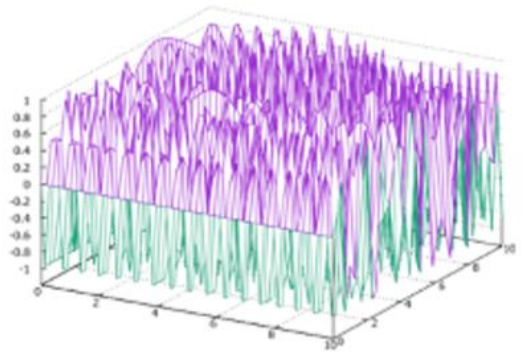

(a)

Short-run period (1 year)

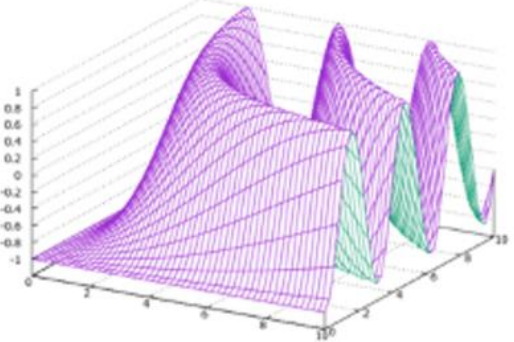

(a) Middle-run period (5-10 years)

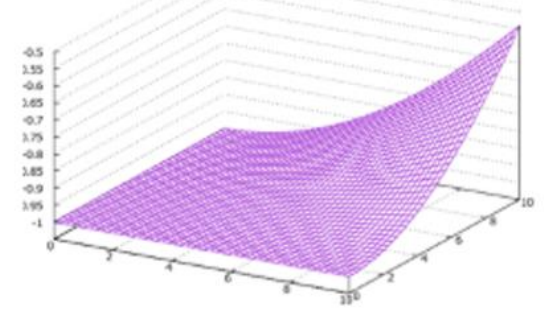

(a)

Long-run period (40-50 years)

Fig. 11. Timing-variability of the generated model
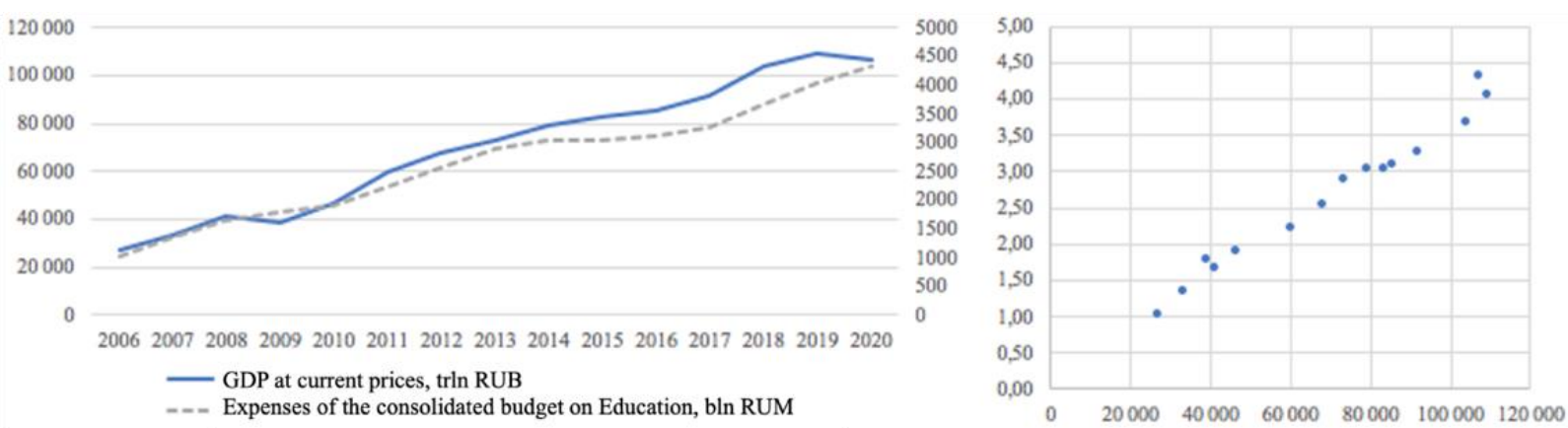

Fig. 12. Initial data for evaluating the model of counter-damping oscillations Source: compiled by the authors based on data from the Ministry of the Finance of Russia and Rosstat 
After having evaluated the model the following results were obtained:

$$
\begin{array}{r}
R O I_{t, l n}=\left(\Delta G D P_{t, l n}-U I_{t, l n}\right)= \\
17,426-0,215 \cdot t+\ln (\cos (4,153 \cdot t)) \\
(0,560) \quad(0,062)
\end{array}
$$

The model parameters are statistically sustainable, and it is also important to note that since the value of the determination coefficient is close to $1(\mathrm{R} 2=0.86)$, the compiled model appears of high quality and evaluation more accurately approximates the observations. The Goldfeld-Quandt test was used to determine the presence of heteroskedasticity. The test is based on the assumptions: the proportionality of the variance of a random disturbance to the magnitude of some regressor; the random disturbance $\varepsilon$ is distributed normally and is not subject to autocorrelation. According to the algorithm of the Goldfeld-Quandt test, the data were ordered by the magnitude of the regressor and the sample of 15 observations was divided into three parts $(n=5)$. Based on the results of the evaluation of auxiliary regressions, statistics with an $\mathrm{F}$-distribution were calculated as next: $\mathrm{GQ}=0,493<\mathrm{F}_{\mathrm{kp}}=3,787 ; \mathrm{GQ}^{-1}=2,027<\mathrm{F}_{\mathrm{kp}}=3,787$. Since both inequalities are met, the null hypothesis about the homoscedasticity of the disturbance is not rejected at a significance level of 0.05 (Babeshko, 2017).

In accordance with the described above, correction of autocorrelation was performed by using the Cochrane-Orcatta method. The prerequisites of Gauss-Markov are fulfilled. The model is of good quality $(\mathrm{R} 2=0.860)$ and is recognized as adequate.

Based on the results of the approximation, it is possible to assert the existence of the effect of counter-damping oscillations in sapiocentric economic systems. However, as already have been highlighted, achieving the "trampoline" effect requires a constant external financial flow, without which the development of science-intensive sectors of the economy and the institutional framework for the reproduction of human capital is impossible. According to the authors, the volume of state funding for education in the Russian Federation is critically insufficient, which creates a risk for the entire economy as a whole: insufficient financing can lead to a change in the coefficient $\lambda$ and generate the damping character of wave activity. In other words, the fact that education is underfunded can reduce human capital not only in the next year, but also reduce the attractiveness of education in the country, the interest of citizens in the development of their own human capital and, as a result, cause irreparable damage to the society in the forecast period of strategic planning.

Thus, the authors consider it is necessary to increase expenditures on education within the framework of the consolidated state budget, as well as, to encourage educational organizations to attract extra-budgetary financing. To assess the necessary changes and based on the results of the construction of the model and the approximation obtained, authors have predicted two alternatives for the development of the economic system of Russia: current (negative) and prospective (positive), which are shown in (Figure 13).

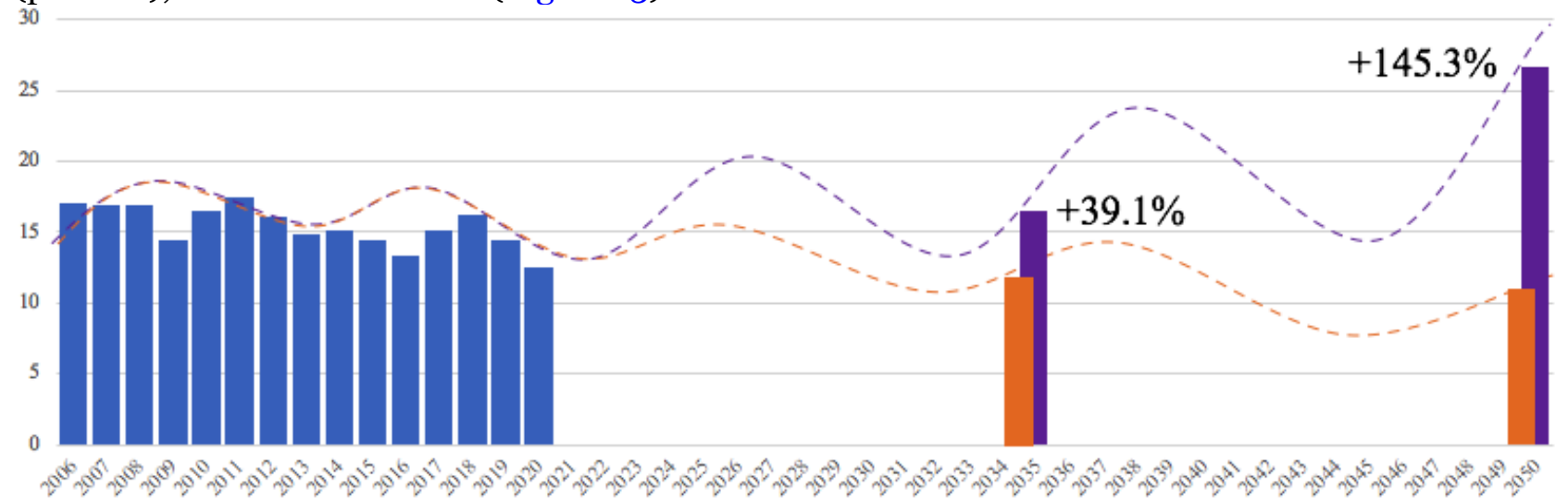

Fig. 13. Approximation and forecast of return on investment into educational infrastructure in the Russian Federation

Source: compiled by the authors based on the calculations according to the data of the Ministry of Finance of Russia and Rosstat 
As a result of the failure to achieve the described effect in the Russian Federation by 2021 the trend of damping oscillations and the emergence of new risks are remaining as in the formation of human capital as in the modern education system. In addition, it is worth highlighting that an increase in investments into educational infrastructure and in the processes of integration of students of higher educational institutions into student science, both through international cooperation and in other ways, by at least 10.52 billion rubles a year makes it possible to achieve a "trampoline" effect in Russia's economic growth and, thereby, increase GDP growth by an average of $2.79 \%$ until 2035 or by $5 \%$ until 2050, what will have a total impact on goods and services output growth to $145.1 \%$.

\section{Discussion}

By a properly structured policy for involving young people in the scientific environment, it is possible to create conditions what will allow to enrich the scientific experience of students, postgraduates and young scientists through close interaction with foreign colleagues and, at the same time, to promote domestic science.

Active international cooperation of higher educational institutions in the scientific field as an organization, as well as the cooperation of individual tutors engaged in scientific projects at the international level, contribute to the development of the interest of young people in participating in scientific activities as such, and, as a result, help to perceive the educational process at their university from a different perspective.

The data of the conducted research demonstrates that three-quarters of the total number of students at universities are interested in international research cooperation, since they see in it, among other things, opportunities for high-quality and significant professional and personal development. The respondents consider spontaneous and direct interaction with foreign colleagues, the prospects of the research activities, as well as the availability of institutional support for young researchers to be the important criteria for effective research cooperation as part of international teams.

The Center for the Support of International Youth Studies plays an important role in supporting the development of international youth research cooperation, as it is a single platform for providing comprehensive academic, organizational, informational support for horizontal cooperation of young researchers.

\section{Conclusion}

To summarize described above, it should be highlighted that the desire for self-realization and self-organization in the form of joining efforts to achieve certain goals is typical for young people as a social and aged community of people. This organic mental property of the younger generation is called cooperation. The external form of cooperation is various kinds of organizations, associations, unities, unions, etc. These associations are typical for schools, colleges, lyceums and higher educational institutions - universities, academies and institutes.

At the same time, it should be noted that youth cooperation is performed both in the form of independent global organizations to what representatives of student communities of various states join, and in the form of interuniversity integration associations.

It should be noted that the study of the experience of leading Russian higher educational institutions associated with the cooperative participation of Russian students in scientific activities is of great interest for scientific comprehension. These cooperative forms include the creation of specialized centers and departments for the development of international activities, the formation of scientific and educational centers for executing national projects, international research performed by teams with foreign participation. In addition, such forms of scientific cooperation as international conferences, international scientific symposiums, international scientific round tables and seminars are actively conducted.

Russian student cooperation should adopt positive international experience. It is obvious that the American and German experience of students' cooperation associated with the active involvement of students in project activities to create startups, what means modeling ideas that require practical implementation in day-to-day life activities and attracting material resources for development, deserves interest by scientists. It is obvious that the future vector of development of Russian students' cooperation will be associated with close interaction of scientific and practical components of the 
educational process. The development of cooperative movements among students requires the creation of additional stimulating organizational, financial and legal mechanisms.

\section{Acknowledgements}

The article is published in the framework of research on the state assignment of the Financial University under the Government of the Russian Federation).

\section{References}

Adams, 2012 - Adams, J. (2012). Collaborations: The rise of research networks. Nature. 490(7420): 335-336.

AIESEC, 2021 - AIESEC, 2021. [Electronic resource]. URL: https://aiesec.org/about-us (date of access: 24.03.2021). [in Russian]

American Psychological Association, 2014 - American Psychological Association (2014). Publication Practices \& Responsible. Authorship. [Electronic resource]. URL: http://www.apa.org/ research/responsible/publication/

Babeshko, 2017 - Babeshko, L.O. (2017). Prognozirovanie finansovo-ekonomicheskikh pokazatelei po raznorodnym dannym: monografiya [Forecasting of financial and economic indicators based on heterogeneous data: monograph]. Moskva: Rusains, 353 p. [in Russian]

Dolzhenko i dr., 2019 - Dolzhenko, R.A., Karpilyansky, V.A., Hadi, R.A., Didenko, A.S. (2019). Motivatsiya molodykh uchenykh $\mathrm{k}$ nauchno-issledovatel'skoi deyatel'nosti $\mathrm{v}$ rossiiskikh regional'nykh vuzakh [Motivation of Young Scientists to Research Activities in Russian Regional Universities]. Obrazovanie i nauka. 21(9): 122-153. [in Russian]

Georgalakis, Rose, 2019 - Georgalakis, J., Rose, P. (2019). Exploring Research-Policy Partnerships in International Development. IBS Bulletin. 5O(1). DOI: https://doi.org/10.19088/ 1968-2019.103

Mezhdunarodnaya molodezhnaya palata - Mezhdunarodnaya molodezhnaya palata [Junior Chamber International]. [Electronic resource]. URL: https://ru.wikipedia.org/wiki/ (date of access: 24.03.2021). [in Russian]

Pisarenko, 2021 - Pisarenko, D. (2021). Rossiya v gonke vychislenii [Russia in the Computing Race]. AIF. 8: 15. [in Russian]

Sapryka i dr., 2016 - Sapryka, V.A., Gukova, I.N., Pastyuk, A.V. (2016). Osobennosti realizatsii molodezhnykh proektov prigranichnogo sotrudnichestva [Features of the implementation of youth projects of cross-border cooperation]. Kazanskii pedagogicheskii zhurnal. 114(1). [in Russian]

Vovenda, 2013 - Vovenda, A.V. (2013). Molodezhnye organizatsii: ikh vliyanie na mirovuyu praktiku [Youth organizations and their role in world politics]. Vestnik MGIMO Universiteta. 29(2). [in Russian]

WFMS, 2021 - WFMS, 2021. [Electronic resource]. URL: https://ru.wikipedia.org/wiki/ Всемирный_фестиваль_молодёжи_и_студентов (date of access: 24.03.2021). [in Russian] 